\title{
Study of barium sulfate dissolution by scale dissolver based on solutions of DTPA
}

\author{
GEIZILA A.P. ABIB, GEORGIANA F. DA CRUZ and ALEXANDRE S.L. VAZ JUNIOR
}

Laboratório de Engenharia e Exploração de Petróleo/LENEP, Setor de Geologia e Geoquímica, Universidade Estadual do Norte Fluminense Darcy Ribeiro/UENF, Av. Brennand, s/n, Rodovia Amaral Peixoto, Km 163, Imboacica, 27925-535 Macaé, RJ, Brazil

Manuscript received on September 14, 2017; accepted for publication on April 4, 2018

\begin{abstract}
In offshore oil wells it is very common to perform seawater injection through injection wells for hydrocarbon recovery. When seawater, rich in sulfate ion, mixes with formation water, whose composition can contain divalent cations such as barium and calcium, it often leads to sulfate salts formation due to their chemical incompatibility. These salts can cause serious damage in production wells. The barium sulfate $\left(\mathrm{BaSO}_{4}\right)$ is the most problematic scale and may cause many complications. In order to solve this issue, polycarboxylic acids, such as diethylene triamine pentaacetic acid, are used. Thus, the primary focus of this work was to develop an experimental procedure to study the $\mathrm{BaSO}_{4}$ dissolution. Initially, through static tests to understand the relationship between dissolver concentration, temperature and dissolution time, and then through dynamic tests in sandstone reservoirs. Based on the results obtained, in the static tests the best condition for barite to dissolve was at high temperatures $\left(80^{\circ} \mathrm{C}\right)$ and contact time of 48 hours, since from $50{ }^{\circ} \mathrm{C}$ there is an increase in dissolution rate, associated with a long contact time between dissolver and barite. In the dynamic tests, after scale formation, barite could be removed, but the high DTPA concentration should be avoided.
\end{abstract}

Key words: Mineral scale, barite, oil reservoir, formation damage.

\section{INTRODUCTION}

During the oil production phase, the reservoir primary energy needs to be supplemented, and so the secondary recovery process is necessary. The water injection through wells is the most common practice, and in offshore productions, seawater $(\mathrm{SW})$, which is rich in ion sulfate $\left(\mathrm{SO}_{4}^{2-}\right)$ is usually injected. The reservoir is saturated with formation

Correspondence to: Georgiana Feitosa da Cruz

E-mail: georgiana@lenep.uenf.br

Geizila Aparecida Pires Abib

E-mail: geizilala@yahoo.com.br water (FW), which contains ions such as barium $\left(\mathrm{Ba}^{2+}\right)$ and calcium $\left(\mathrm{Ca}^{2+}\right)$ and, therefore, the mixture between these waters within the rock porous can promote the deposition of mineral scales, which consist of salt with low solubility in water (Dunn et al. 1999, Shaw et al. 2012, Bin Merdhah and Yassin 2008a). The most common scales in the petroleum industry are calcium sulfate $\left(\mathrm{CaSO}_{4}\right)$, calcium carbonate $\left(\mathrm{CaCO}_{3}\right)$ and barium sulfate $\left(\mathrm{BaSO}_{4}\right)$. This latter is known as barite and has an important feature, remains practically insoluble in water and acid, due to its low solubility, which gives it 
the chemical inertia property (Dunn et al. 1999, Bin Merdhah and Yassin 2008b, Bin Merdhah et al. 2010). However, it is possible to find solubility values between 2.0 and $2.5 \mathrm{mg} \mathrm{L}^{-1}$ at $25^{\circ} \mathrm{C}$ in water and solubility product $\left(\mathrm{K}_{\mathrm{sp}}\right)$ values equal to 1.02 $10^{-10} \mathrm{~mol} \mathrm{~L}^{-1}$ at $25^{\circ} \mathrm{C}$, which makes this salt more difficult to remove (Wang et al. 1999, Harris 2001). The formation of insoluble salts, which are deposited in rock pores and in production equipment, might reduce or block the rock pore throat and damage several equipment causing subsequent financial loss. The region near production wells is the most affected one (Economides and Nolte 2000, Mackay 2003, Mackay et al. 2003, Kalfayan 2008), therefore, when the scale potential is known, the use of preventive and corrective methods is necessary to solve the mineral scale deposition issues.

The scale control by chemical inhibitors application is normally used as a preventive method. It consists of injections of substances which are capable of controling the scale formation by preventing crystal formation stages such as nucleation, crystal growth and dispersion. The scale prevention, normally, uses the squeeze treatments in which inhibitors are injected into the production well. However, there are scenarios in which scale inhibition alone is not enough, and scale deposits formation may occur. In some cases, a combination of preventive and corrective methods is necessary. This latter consists of removing the existing damage either by mechanical techniques (milling, jetting, fracturing of scale) or chemical products (treatments by inorganic acids or polycarboxylic acids) (Bellarby 2009, Tomson et al. 2003, Reis et al. 2011, Fink 2012). The barite scale is very hard and only polycarboxylic acids are able to remove it. The diethylene triamine pentacetic acid (DTPA), which is a strong cation chelating agent, is one of the most used in the oil industry. This chelating agent is injected into the production well and it is able to remove the salt by forming metal complexes. Although there are several studies in the literature and removal processes by industry, laboratory test studies on static and dynamic barite deposition and subsequent removal are still little widespread and complex (Dunn et al. 1999, Bin Merdhah and Yassin 2008b). Also, chemical factors affecting this reaction are not fully known, leading to conflicting results on treatment effectiveness (A.V. Shende, unpublished data).

Therefore, a methodology to study barium sulfate dissolution through static test with DTPA and, subsequently dynamic test with injection of dissolver into a porous medium which simulates a reservoir rock, is of considerable importance. Despite that, there is still no work in the literature that compiles these methodologies in an integrated manner to approach this matter. Hence, this work intends to offer a comprehensive methodology in the barium sulfate scale study, starting with the static test and then through with the dynamic test.

Chemistry knowledge on composition of waters FW and SW and DTPA solution is necessary for this study. The ion chromatography (IC) has extensive analytical application and provides an alternative method to classical techniques (gravimetric, volumetric e.g.) to determine ions with speed, efficiency and low effort. In the oil industry this technique can determine the concentration of ions present in fouling water, providing information about the scale formation process and its trend rate and also about inhibitors efficiency (Atwood and Wallwey 1996, Collins et al. 2006, El-Said et al. 2009) since IC allows different cations and anions determination, including sodium $\left(\mathrm{Na}^{+}\right)$, barium $\left(\mathrm{Ba}^{2+}\right)$, chloride $\left(\mathrm{Cl}^{-}\right)$and sulfate $\left(\mathrm{SO}_{4}^{2-}\right)$, which are present in the formation and injection water as well as the mineral scale. So IC was used to quantifiy previous ions present in the solutions of both tests.

Thus, this work sets experimental procedures to study the dissolution of the $\mathrm{BaSO}_{4}$ scale by chelating agent. Initially, $\mathrm{BaSO}_{4}$ static dissolution tests were performed varying temperature, dissolution concentration and dissolution time 
conditions, which are important factors for the chemical reaction. Based on the preliminary results, it was possible to develop an experimental protocol for dynamic tests with monophasic and biphasic flow, including damage formation - $\mathrm{BaSO}_{4}$ precipitation inside rock pores - and subsequent DTPA removal.

\section{MATERIALS AND METHODS}

This work covers two steps, first the application of static tests to evaluate the effects of barite dissolution by DTPA in bench tests, varying their concentration, temperature and reaction time between the barite and dissolver; and second the use of dynamic tests with mono-phase and twophase flow, including the damage formation and subsequent removal. Information about equipment, reagents, samples and procedures are described in the respective sub-sections.

\section{INSTRUMENTATION}

The FW, SW and DTPA solutions were prepared using ultrapure water obtained from Milli-Q Direct-Q 5 MILLIPORE water purification system. The fouling salts and samples (barite and core material) were measured by the analytical balance Shimadzu model AUY 220. The bench pHmeter model 827 Metrohm was used to measure this parameter. The ions quantification was performed using the ion chromatography (IC) with sampler and conductivity detection, model 850 Professional IC, equipped with pump 833 Liquid Handling Unite, 858 Professional Sample Processor, and the chromatographic columns employed were Metrosep C2 150/4.0 mm for cations, and Metrosep A Supp5 $150 / 4.0 \mathrm{~mm}$, for anions. To observe the pits on the barite surface and rock sections the scanning electron microscopy (SEM) - TM3000 Tabletop Microscope, HITACHI, and the energy dispersive X-ray spectroscopy (EDS) EDS SwiftED3000 were employed.
The dynamic tests were performed using a confinement cell, type core holder, Labconte, and a constant flow pump, model PU-2087 plus- Jasco, and a manual hydraulic pump model 700HTP1, FLUKE, for fluid injection. Pressure values measured during this tests were collected using a computer, the software LabView, along with the differential pressure transducer model EJA 130A/ S1, Yokogawa, and gauge 316 SS, Swagelok. The dimensions of core material were measured with the digital caliper, DIGIMESS. The DTPA solution was injected using the transfer bottle, Labconte.

Other equipments used were the drying and sterilizing oven New Ethics 200/2ND and the system saturation and vacuum filtration.

\section{MATERIALS AND REAGENTS}

Analytical grade reagents were used to prepare all eluents, standard stock solutions, supplied Merck. The eluents used for analysis with IC, were dihydrate oxalic acid $\left(\mathrm{C}_{2} \mathrm{H}_{2} \mathrm{O}_{4} \cdot 2 \mathrm{H}_{2} \mathrm{O}\right)$ - eluent for cations; sodium carbonate $\left(\mathrm{Na}_{2} \mathrm{CO}_{3}\right)$ and sodium bicarbonate $\left(\mathrm{NaHCO}_{3}\right)$ - eluents for anions; sulfuric acid $\left(\mathrm{H}_{2} \mathrm{SO}_{4}\right)$ 95-97\% - regenerating solution. The barium determinations were calibrated by measuring five standard solutions. Standard solutions were prepared from $\mathrm{BaCl}_{2}$ solutions to build the calibration curve (coefficient correlation, $R=0.999807$ and stadard deviation, $\mathrm{SD}=1.8 \%$ ). To prepare the $\mathrm{SW}$ were used sodium sulfate $\left(\mathrm{Na}_{2} \mathrm{SO}_{4}\right)$ and sodium chloride $(\mathrm{NaCl})$, for the $\mathrm{FW}$ were used barium chloride $\left(\mathrm{BaCl}_{2} \cdot 2 \mathrm{H}_{2} \mathrm{O}\right)$ besides $\mathrm{NaC} \ell$. The composition of fouling water is shown in Table I.

TABLE I

Composition of FW and SW waters used in dynamic tests.

\begin{tabular}{ccc}
\hline Ions & $\mathrm{FW}-\left(\mathrm{mg} \mathrm{L}^{-1}\right)$ & $\mathrm{SW}-\left(\mathrm{mg} \mathrm{L}^{-1}\right)$ \\
\hline $\mathrm{C}^{-}$ & 51779 & 21300 \\
$\mathrm{Na}^{+}$ & 33500 & 14490.76 \\
$\mathrm{Ba}^{2+}$ & 229 & - \\
$\mathrm{SO}_{4}^{2-}$ & - & 2834 \\
\hline
\end{tabular}


The DTPA solutions were prepared from following the commercial products Versenex K, Dequest 2066A, Ultranex NP 100 and DTPA. The dissolver solution's components and its respective functions are shown in Table II.

The barite samples were obtained by precipitation of this salt within production wells from the Campos basin, Brazil, during the production step. While in surface conditions, the barite received cleansing and purification treatments (including free radioactivity). The samples were kindly provided by CENPES/Petrobras and are presented in an ellipsoid shape, as shown in Figure 1a.

The core material used for the dynamic core floods came from the Botucatu formation (Botucatu sandstone) in Brazil. The Botucatu Formation comprises clayey rock, silt rock and sandy rock located in northeast of Paraná state and in southwest of São Paulo state (Montanheiro et al. 2011). The core material represents the reservoir rock in this experiment, that is, the scale location, as shown in Figure 1b.

\section{PROCEDURES}

\section{Static test with barite}

Barite dissolution tests were made with precipitate in spheroid forms (real scale), cleaned and radioactivity free. The dissolvers were prepared in three different formulations with $10 \%, 15 \%$ and $25 \%$ DTPA. The information about the base materials used in this preparation and their respective functions are presented in Table II. The tests occurred at temperatures of 23,50 and $80{ }^{\circ} \mathrm{C}$ and time periods of 12, 24 and 48 hours, and the experiments were carried out at $\mathrm{pH}$ levels of 11-12 where the DTPA is effectively deprotonated $(\mathrm{K}$. Wang et al., unpublised data, Putnis et al. 2008). These tests evaluated the dissolution of natural $\mathrm{BaSO}_{4}$ beads through mass variation (initial and final barite mass); the $\mathrm{Ba}^{2+}$ concentration in the supernatant was analyzed with ion chromatographic (IC); pits on the barite surface were analyzed with scanning electron microscopy (SEM) in order to observe the dissolver's chemical attack. Initially, the barite was weighed and then placed into the vials and $1 \mathrm{~mL}$ of dissolver was added. After the dissolution time, a vacuum filtration was performed and both filtrated and remaining barite were analyzed with IC and SEM, respectively.

\section{Dynamic tests}

Several tests were performed during the laboratory step of this research to find the best methodology and best solution to remove mineral scale. Six dynamic

TABLE II

Components of dissolver solution and its respective functions.

\begin{tabular}{|c|c|c|c|c|c|c|c|c|c|}
\hline \multirow{2}{*}{ Components } & \multicolumn{3}{|c|}{ Solution A (10\% DTPA) } & \multicolumn{3}{|c|}{ Solution B (15\% DTPA) } & \multicolumn{3}{|c|}{ Solution C (25\% DTPA) } \\
\hline & Vol (mL) & $\mathrm{pH}$ & $\mathrm{d}^{e}\left(\mathrm{~g} \mathrm{~mL}^{-1}\right)$ & Vol (mL) & $\mathrm{pH}$ & $\mathrm{d}\left(\mathrm{g} \mathrm{mL}^{-1}\right)$ & Vol (mL) & $\mathrm{pH}$ & $\mathrm{d}\left(\mathrm{g} \mathrm{mL}^{-1}\right)$ \\
\hline Versenex $\mathrm{K}^{a}$ & 51.0 & \multirow{4}{*}{11.01} & \multirow{4}{*}{1.03} & 76.0 & \multirow{4}{*}{11.08} & \multirow{4}{*}{1.07} & 123.0 & \multirow{4}{*}{11.13} & \multirow{4}{*}{1.12} \\
\hline Dequest $2066 \mathrm{~A}^{b}$ & 0.75 & & & 0.75 & & & 0.75 & & \\
\hline Ultranex NP $100^{c}$ & 0.25 & & & 0.25 & & & 0.25 & & \\
\hline Ultrapure water $^{d}$ & $\mathrm{SQT}^{f}$ & & & SQT & & & SQT & & \\
\hline
\end{tabular}

${ }^{a}$ DTPA active substance / scale dissolver.

${ }^{b}$ preventer emulsion.

${ }^{c}$ wetting agent.

${ }^{d}$ diluent. Ultrapure water was used to prepare the solutions of static test. But in the injection flow tests the diluent used was 35000 $\mathrm{mg} \mathrm{L}^{-1}$ saline solution.

${ }^{e}$ density.

${ }^{f}$ in sufficient quantities to prepare $250 \mathrm{~mL}$ of solution. 
a)

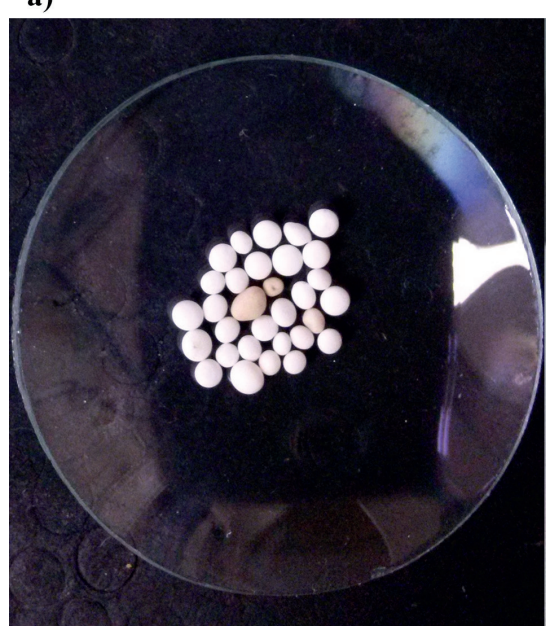

b)

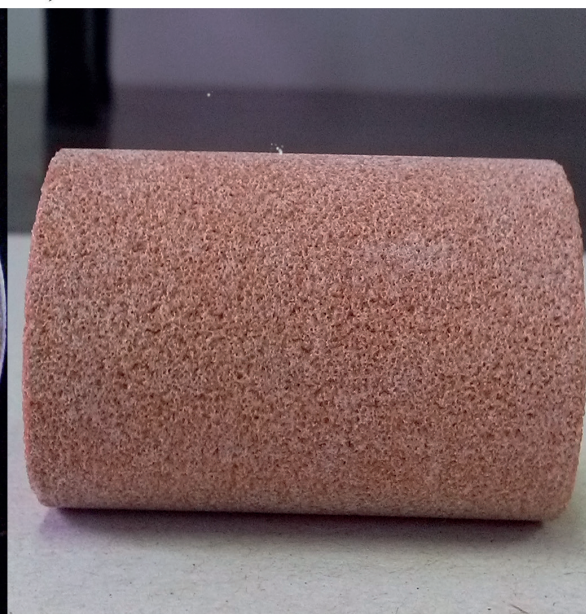

Figure 1 - Samples used in the tests: (a) barite samples $\left(\mathrm{BaSO}_{4}\right)$ used in static test; (b) core material used in the dynamic test (side view).

tests were performed - 5 mono-phase flow tests and 1 two-phase flow test - but only one test of each was shown to represent the methodology proposal.

These tests were subdivided into procedure A, mono-phase flow (brine injection only) and procedure $\mathrm{B}$, two-phase flow (injection of brine and diesel). Core material measurements used were $4.1 \mathrm{~cm}$ length and $2.5 \mathrm{~cm}$ diameter with average porosity of $21 \%$. IC analysis and SEM, combined with dispersive X-ray energy spectroscopy (DES), were also used.

\section{Procedure A-test 1}

Initially, the core material was saturated with formation water (FW) under vacuum and then it was assembled in a cell with a confining pressure of $1500 \mathrm{psi}$. The core was shut in and heated in an oven at $50{ }^{\circ} \mathrm{C}$ for 16 hours, and the original permeability $\left(k_{\text {orig }}\right)$ was measured by FW injection at four flow rates, $2.0 \mathrm{~mL} \mathrm{~min}^{-1}, 1.5 \mathrm{~mL} \mathrm{~min}^{-1}, 1.0 \mathrm{~mL} \mathrm{~min}^{-1}$ and $0.5 \mathrm{~mL} \mathrm{~min}^{-1}$, through the use of Darcy's Law, since it is the most used equation for flow measurement in porous medium (Rosa et al. 2006). The Darcy's Law (Equation 1) is:

$q=\frac{k A \Delta P}{\mu L}$ $q=$ flow rate $\left(\mathrm{m}^{3} \mathrm{~s}^{-1}\right)$

$k=$ permeability (mili Darcy)

$A=\operatorname{area}\left(\mathrm{m}^{2}\right)$

$\Delta \mathrm{P}=$ pressure differential $(\mathrm{Pa})$

$\mu=\operatorname{viscosity~(Pa.s)~}$

$L=$ length (m)

Then, the FW and seawater (SW) brines were injected through separated lines, simultaneously, at $0.5 \mathrm{~mL} \mathrm{~min}{ }^{-1}$ each solution, in order to promote formation damage within the rock porous. Effluent samples were collected along the injection. A damaged permeability $\left(k_{d a m}\right)$ was measured with FW, after the simultaneous injection. Then, around $100 \mathrm{~mL}$ of $15 \%$ DTPA in solution was injected at 1.0 $\mathrm{mL} \mathrm{min}^{-1}$ order to promote the scale removal and, after 24 hours (soak time) the third permeability was measured to evaluate the original permeability recovery, the final permeability $\left(k_{\text {final }}\right)$. The effluent samples collected during the tests (FW and SW injection) were analyzed with IC and core sections were analyzed with SEM. It is important to point out that the DTPA solution used in this procedure was prepared with saline instead of ultrapure water, otherwise it could cause fines migration due to low salinity and, consequently, porosity and permeability drop. 


\section{Procedure B - test 2}

The same steps used in Procedure A were employed until the first permeability $\left(k_{\text {orig }}\right)$ measurement. Then, a consecutive oil-water-oil injection at 1.0 $\mathrm{mL} \min ^{-1}$ was performed, in order to measure the oil and water relative permeability $\left(k_{r o}\right.$ and $\left.k_{r w}\right)$, residual oil saturation $\left(S_{o r}\right)$ and irreducible water saturation $\left(S_{w i}\right)$. The FW and $\mathrm{SW}$ brines were injected simultaneously (at $0.5 \mathrm{~mL} \mathrm{~min}^{-1}$ each solution) to induce damage within the rock. During the damaging stage, effluent samples were collected. Second oil and water injections were performed with flow rate of $1.0 \mathrm{~mL} \mathrm{~min}{ }^{-1}$ each, in order to measure $k_{r o}, k_{r w}, S_{o r}$ and $S_{w i}$ after induced damage formation. Then, around $100 \mathrm{~mL}$ of $25 \%$ DTPA in solution at $1.0 \mathrm{~mL} \mathrm{~min}^{-1}$ was injected and, after 24 hours (soak time), a third water and oil injection was performed to measure new values of $k_{r o}, k_{r w}, S_{o r}$ and $S_{w i}$ after dissolver application.

\section{RESULTS AND DISCUSSION}

\section{STATIC TEST}

The static tests were performed in triplicate for each condition assessed involving different temperatures $\left(23^{\circ} \mathrm{C}, 50^{\circ} \mathrm{C}\right.$ and $\left.80^{\circ} \mathrm{C}\right)$, time periods (12h, $24 \mathrm{~h}$ and $48 \mathrm{~h})$ and concentrations $(10 \%, 15 \%$ and $25 \%$ ). The barite mass presented a decrease in all tests; dissolved barite mass percentage was obtained by gravimetry along the time period of each concentration and it is shown in Figure 2. Temperature effect in static tests, without the saline water presence, could show a proportional relationship between temperature and $\mathrm{BaSO}_{4}$ dissolution, because salt solubility increased with temperature increase for all solutions. Since the activation energy is directly associated with temperature, it can be said that temperature is the control factor of the reactions that occur on the barite crystal surface leading to its dissolution (Bin Merdhah et al. 2010, Jordan et al. 2000).
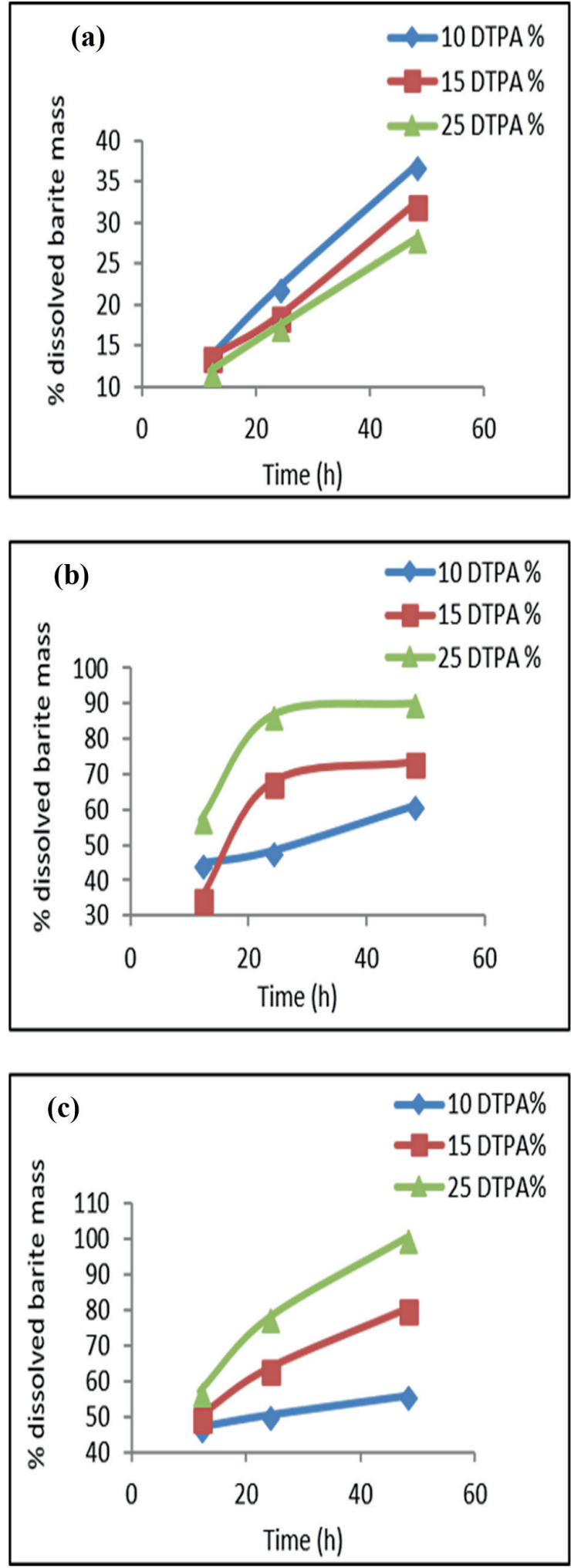

Figure 2 - Dissolved barite mass (\%) versus residence time (h) for static test at $23{ }^{\circ} \mathrm{C} \mathrm{(a),} 50{ }^{\circ} \mathrm{C}$ (b) and $80{ }^{\circ} \mathrm{C}$ (c) for $10 \%, 15 \%$ and $25 \%$ DTPA in solution, respectively. 
So then, at high temperatures, a larger dissolved barite mass was obtained. Similar results were observed with time influence, since longer contact time between barite and solution caused higher solubility. M.M. Jordan et al. (unpublished data) reported that the $\mathrm{BaSO}_{4}$ dissolution at temperatures below $40{ }^{\circ} \mathrm{C}$ is poor, and that from $50{ }^{\circ} \mathrm{C}$ there is an improvement in the dissolution rate. It was also observed in this work, that the highest dissolved mass percentage values was from $50{ }^{\circ} \mathrm{C}$. Thus, for the static tests performed in this work, the highest barite dissolution value was at $80{ }^{\circ} \mathrm{C}$ with contact time of 48 hours at high $\mathrm{pH}(11-12)$, for all DTPA concentrations.

The results concerning the effect of DTPA concentration in solution show no proportionality between the dissolver concentration and barite dissolution once the significant increase of dissolved barite mass was noticed only from $50{ }^{\circ} \mathrm{C}$, for all three DTPA concentrations. As DTPA molecules are large, a high concentration may cause a shielding layer formation (agglutination of DTPA molecules) on the surface of barite, interfering in the removal efficiency. This shielding layer may be broken by increasing the dissolution temperature since this process is endothermic ( $\mathrm{K}$. Wang et al., unpublished data, Putnis et al. 2008). Thus, these results suggest that at low temperatures, in the absence of interferences and without taking into account the effects of pressure, excess DTPA becomes detrimental to the precipitated salt dissolution. In this case, a better employment of DTPA could be achieved if the dissolver solution was less concentrated. However further tests are still necessary to confirm this hypothesis.

Figure 3 shows the $\mathrm{Ba}^{2+}$ concentration from the dissolved barite mass, which was present in the supernatant. Then, dilutions were made and the resulting solutions were analyzed with IC. These results present the values for free $\mathrm{Ba}^{2+}$, the scale ion, not complexed with DTPA and the total $\mathrm{Ba}^{2+}$,
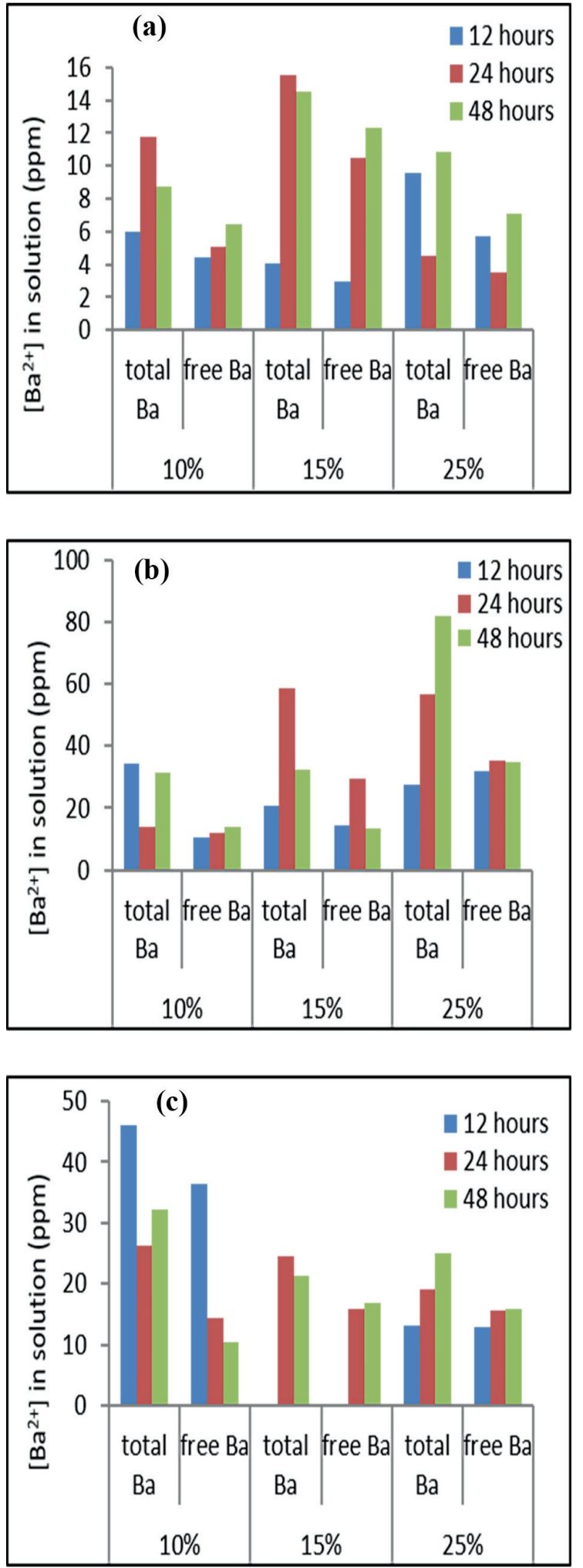

Figure 3 - Concentration $\left(\mathrm{mg} \mathrm{L}^{-1}\right)$ of total $\mathrm{Ba}^{2+}$ and free $\mathrm{Ba}^{2+}$ in supernatant at $23{ }^{\circ} \mathrm{C}(\mathbf{a}), 50^{\circ} \mathrm{C}(\mathbf{b})$ and $80{ }^{\circ} \mathrm{C}(\mathbf{c})$, analyzed by ion chromatography IC. 
which is $\mathrm{Ba}^{2+}$ ion existent into supernatant in free and complexed forms.

Although the stoichiometry of the reaction is not completely known, the literature presents the equimolar ratio between DTPA and $\mathrm{Ba}^{2+}$ as $1: 1$, according to Equation 2. This chemical equation shows the dissolution reaction and the stability constant $\left(\mathrm{K}_{\mathrm{st}}\right)$ of chelate formed between barium ions and DTPA (Ba-DTPA ${ }^{3-}$ ) (Wang et al. 1999, K. Wang et al., unpublished data, Putnis et al. 2008).

$$
\begin{aligned}
& \mathrm{BaSO}_{4(s)}+\mathrm{DTP}_{(a q)}^{5-} \rightarrow \mathrm{BaDTPA}_{(a q)}^{3-}+\mathrm{SO}_{4(a q)}^{2-} \\
& \log K_{s t}=8.78
\end{aligned}
$$

Thus, the difference between the total $\mathrm{Ba}^{2+}$ and free $\mathrm{Ba}^{2+}$ ions corresponds with the complexed $\mathrm{Ba}^{2+}$ ions, since the dissolver solutions had adequate amounts of DTPA molecules to react with. Therefore, it was observed that the total $\mathrm{Ba}^{2+}$ concentration was bigger than the free $\mathrm{Ba}^{2+}$ in all tests, indicating that the largest amount of $\mathrm{Ba}^{2+}$ ions was complexed with DTPA.

After contact between DTPA and barite crystal, the barite crystal wears out in surface area and gets corrosion points due to detachment of the barium ion from barium sulfate. Hence, the formed ionremover complex is responsible for the disruption of the bonds that hold the fouling core intact and thus with presence of the scale dissolver, the deposit is gradually removed, and so one portion of barium ion is complexed and another is free.

The barite dissolution can also be observed on images of SEM, which show the pits on barite surface and testify the chemical attack caused by DTPA. These pits have become more profound as the dissolution conditions were more severe (higher contact time, higher temperatures and higher remover concentrations). The Figure S1a (Supplementary Material) shows a barite image before the test (without remover solution) with a resolution of $40 \mathrm{x}$. It is possible to observe that the shape of the barite is relatively regular, smooth and homogeneous.

Figure S1b, c and d also indicates corrosion points and grooves on the surface of the barite, which became deeper under more severe conditions. The images obtained with SEM were important to observe and check the action of the dissolver solutions on $\mathrm{BaSO}_{4}$ dissolution, and it can be seen that the 25 DTPA $\%$ solution at $80{ }^{\circ} \mathrm{C}$ and 12 hours dissolution time was the most efficient condition, as noted in the evaluation of the dissolved mass percentage.

\section{DYNAMIC TESTS}

\section{Mono-phase flow test}

The mono-phase flow test results showed the variation of absolute permeability. Figure 4, through application of Darcy's Law, shows the reduction of $k_{\text {orig }}(\sim 119 \mathrm{md})$ after damage to $k_{\text {dam }}(\sim 68 \mathrm{md})$, and the $k_{\text {final }}(\sim 118 \mathrm{md})$ after removal of the damage. The calculations applied the corrected value of viscosity equal to $0.610^{-3} \mathrm{~Pa}$.s at $50^{\circ} \mathrm{C}$. These three permeability values, represented by the curves, showed that it was possible to reduce the original permeability value due to the mixture of the FW and SW waters and the consequent precipitation of $\mathrm{BaSO}_{4}$ into the pores of the rock, obstructing the flow, which is, considerably reducing the rock original permeability. However, after treatment of the core material with DTPA dissolver, the permeability increased (final permeability value) because the $\mathrm{BaSO}_{4}$ was dissolved and there was an original permeability recovery. Nevertheless, the high permeability recovery value (almost 100\%) could come from some rock stimulation, caused by a chemical reaction between dissolver and rock minerals, and thus contributing to a considerable increase in the rock's original permeability, which was also observed in some works in the literature (Todd and Yuan 1992, Ali et al. 2008). 


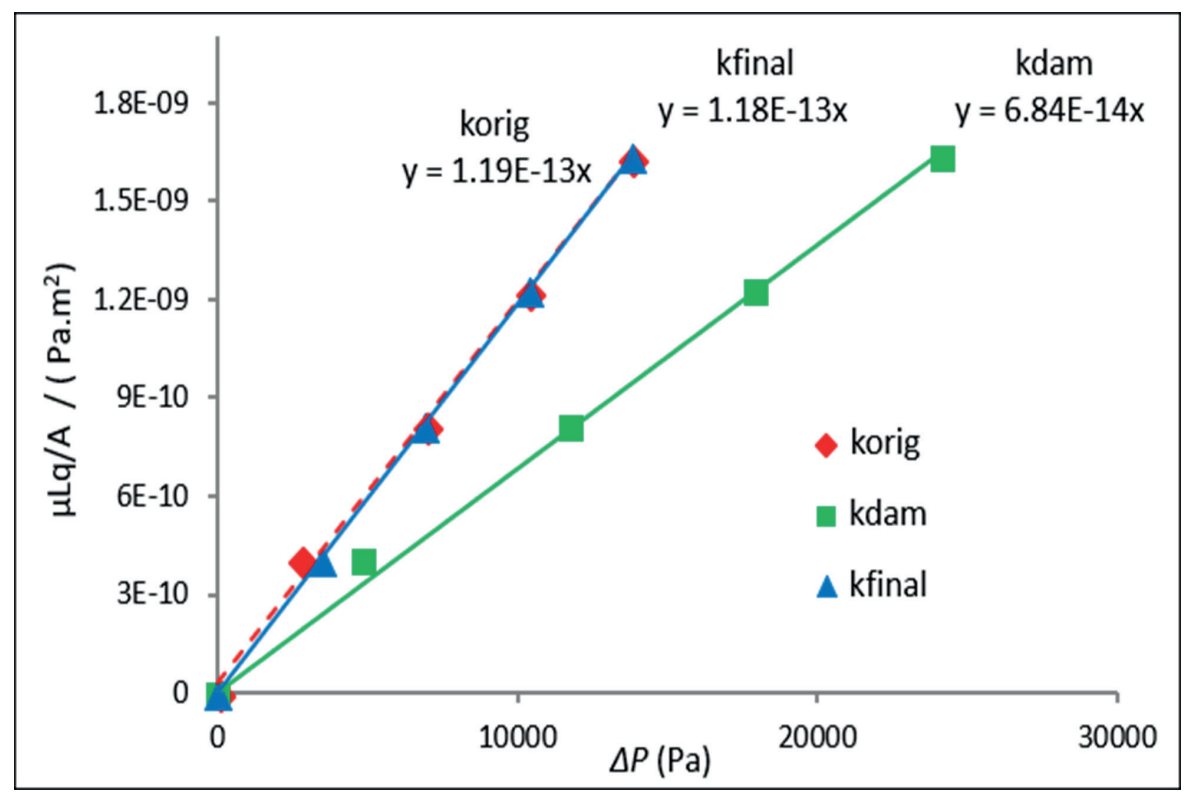

Figure 4 - Measurement of original $\left(\mathrm{k}_{\text {orig }}\right)$, damaged $\left(\mathrm{k}_{\mathrm{dam}}\right)$, and final permeabilities $\left(\mathrm{k}_{\text {final }}\right)$ from the Darcy law for the mono-phase flow test (15\% DTPA/24h).

In addition to the permeability values obtained through Darcy's Law, the effluent samples from mono-phase flow test were analyzed with IC and Table III shows the concentrations of $\mathrm{Ba}^{2+}$ and $\mathrm{SO}_{4}^{2-}$ in the effluents during the damaging stage and removal stage. During damaging stage (simultaneous injection of FW and SW waters) there was significant reduction in concentration of $\mathrm{Ba}^{2+}$ in the effluent due to the chemical reaction between this ion and $\mathrm{SO}_{4}^{2-}$, leading to $\mathrm{BaSO}_{4}$ scale formation in the rock pore, which caused a significant permeability loss, a reduction of $42 \%$ from the original permeability. On the other hand, there was an increase in the concentration of $\mathrm{Ba}^{2+}$ in the effluent from removal due to dissolution process which breaks the scale structure. The IC was capable of detecting the ion $\mathrm{Ba}^{2+}$, even in samples with high concentrations of other typical ions in salt water, such as sodium $\left(\mathrm{Na}^{+}\right)$and potassium $\left(\mathrm{K}^{+}\right)$, as also reported in the literature (Atwood and Wallwey 1996).

To confirm the presented methodology and illustrate the $\mathrm{BaSO}_{4}$ precipitation as a result of the mixture between FW and SW waters, Figure
TABLE III

Concentration $\left(\mathrm{mg} \mathrm{L}^{-1}\right)$ of $\mathrm{Ba}^{2+}$ and $\mathrm{SO}_{4}^{2-}$ obtained by IC from mono-phase flow test.

\begin{tabular}{ccc}
\hline \multirow{2}{*}{$\begin{array}{c}\text { Scaling waters/ } \\
\text { effluents }\end{array}$} & \multicolumn{2}{c}{ Concentration $\left(\mathrm{mg} \mathrm{L}^{-1}\right)$} \\
\cline { 2 - 3 } $\mathrm{SW}^{a}$ & $\mathrm{Ba}^{2+}$ & $\mathrm{SO}_{4}^{2-}$ \\
\hline $\mathrm{FW}^{b}$ & - & 2836.25 \\
$\mathrm{ED}^{c} 1$ & 226.12 & - \\
$\mathrm{ED}^{2}$ & 9.42 & 1182.25 \\
$\mathrm{ED} 3$ & 12.70 & 1243.50 \\
$\mathrm{ED}^{2}$ & 11.15 & 1308.25 \\
ER & 9.40 & 1367.50 \\
ER2 & 203.27 & 281.50 \\
ER3 & 110.95 & 149.25 \\
ER4 & 79.17 & 110.25 \\
\hline
\end{tabular}

${ }^{a}$ sea water.

${ }^{b}$ formation water.

${ }^{c}$ ED1 to ED4 = samples of effluents collected during formation damage stage.

${ }^{d}$ ER1 to ER4 = samples of effluents collected during removal of damage stage.

S2a shows EDS spectrum and 2Sb SEM image. Figure S2b shows a SEM image of a rock sample with $\mathrm{BaSO}_{4}$, obtained from extra tests performed using only scaling waters injection and without 
the removal step. The identification and chemical elements quantification with EDS was made for the demarcated section. This area was chosen after scanning all surface rocks and only at this point identifying the presence of barium, sulfate and oxygen. Others crystalline materials were found, but they contained sodium and chloride. In this section, the dispersive X-ray energy spectrum for chemical elements quantification was made, as shown in Figure S2a. It was possible to observe, besides the common elements in sandstone rocks, the presence of sulfur (S) and barium (Ba) elements, along with oxygen $(\mathrm{O})$ element, which are part of the chemical composition of the referred mineral scale.

Therefore, Figure $2 \mathrm{~S}$ showed that the methodology can represent the real damage caused by scaling waters injection.

Two-phase flow test

One two-phase flow test was performed to exemplify the methodology proposal. It was possible to observe relative permeability and saturation variations throughout the experiment, during stage 1 (before formation damage), stage 2 (after formation damage) and stage 3 (damage removal) according to Figure 5. The $k_{r o}, k_{r w}$ and $S_{w i}$ (stage 1) decreased after damage formation, while the $S_{o r}$ increased (stage 2). After the damage removal, $k_{r o}$, $k_{r w}$ and $S_{w i}$ increased and the $S_{o r}$ decreased (stage $3)$. These final values are acceptable because a higher $S_{w i}$ indicates a water-wet rock by it and thus a smaller water volume tends to be produced. On the other hand, a low value of $S_{o r}$ means that the rock is less wettable to the oil and, thus, the fluid has low adherence in the rock wall and can be easily produced. Due to the high values found in stage 3, we raise the hypothesis that the DTPA may have improved the original permeability because it reacted with the scale and it may also have reacted with the rock, since a high concentration of this product was used. However, it is necessary to repeat this test to confirm this hypothesis. In the literature, some studies were carried out in which dissolvers

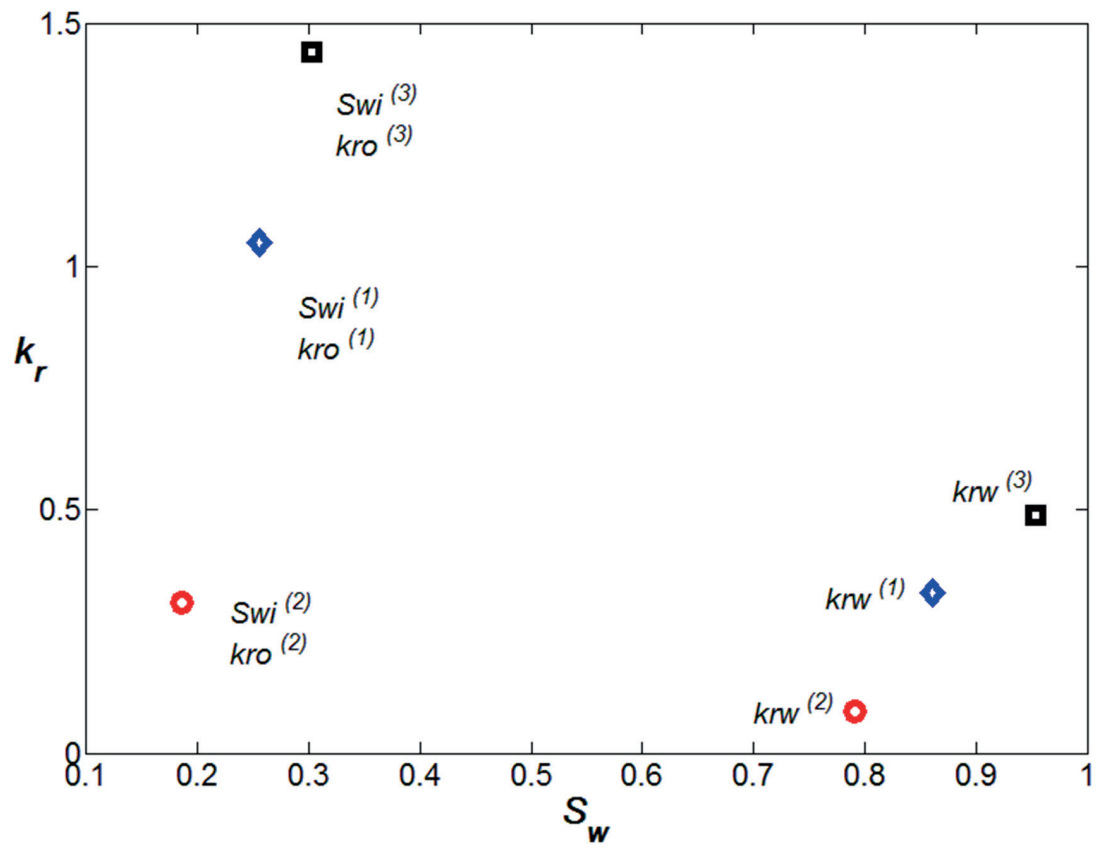

Figure 5 - Variation of relative permeability $\left(k_{r}\right)$ versus water saturation $\left(S_{w}\right)$ for the three moments of two-phase flow test: stage 1 - before damage formation (blue), stage 2 - after damage formation (red) and stage 3 - after removal of damage (black). 
based on DTPA and EDTA dissolved sandstones (Todd and Yuan 1992, Ali et al. 2008).

\section{CONCLUSIONS}

In general, through the proposed experimental procedures, it was possible to study the dissolution of $\mathrm{BaSO}_{4}$ and the parameters (temperature, dissolution time and DTPA concentration) involved. Static tests have enabled prior knowledge on the $\mathrm{BaSO}_{4}$ dissolution study and showed that increasing the temperature and dissolution time were positive factors to achieve disintegration and enhanced scale dissolution. Moreover, this study showed that a high DTPA concentration under low temperatures, below $40{ }^{\circ} \mathrm{C}$, is not efficient for $\mathrm{BaSO}_{4}$ dissolution. Thus, DTPA solutions with a high concentration must be used at higher temperatures and longer dissolution time, in order to avoid the shielding effect. With the dynamic tests (mono-phase and two-phase) it was possible to simulate the damage formation $\left(\mathrm{BaSO}_{4}\right.$ scale) in rock pores through incompatible waters injection, by monitoring the pressure rise, with a decrease in permeability. And moreover, in the two-phase test it was possible to observe the water and oil saturation change as well as the relative permeability change for these fluids, which are the most important measurements for the oil industry. Also, this test represents that the case is closer to a real situation. For both tests, it was possible to remove the scale with great efficiency.

Therefore, the results obtained from static tests were important to understand the influence of factors (curing time, temperature and concentration) in the dissolution process and it contributed to the dynamic tests. Thus, the proposed methodology represents a wide study about the $\mathrm{BaSO}_{4}$ dissolution by DTPA.

Nomenclature:

FW - formation water

SW - sea water

DTPA - diethylene triamine pentacetic acid
IC - ion chromatography

SEM - scanning electron microscopy

EDS - energy dispersive X-ray spectroscopy

$\mathrm{k}_{\text {orig }}$ - original permeability

$\mathrm{k}_{\mathrm{dam}}$ - damaged permeability

$\mathrm{k}_{\text {final }}$ - final permeability

$\mathrm{k}_{\mathrm{ro}}$ - oil relative permeability

$\mathrm{k}_{\mathrm{rw}}$ - water relative permeability

$\mathrm{S}_{\text {or }}$ - residual oil saturation

$\mathrm{S}_{\mathrm{wi}-}$ irreducible water saturation

\section{ACKNOWLEDGMENTS}

The authors would like to thank CENPES/Petrobras for supplying the barite and the other components to prepare the DTPA solutions, and thank PRH20 and Agência Nacional do Petróleo, Gás Natural e Biocombustíveis (ANP) for the financial support. We are also grateful to Mrs. Francisca F. do Rosário for allowing us to use the SEM and to Raquel M. Fedrizzi for preparing the SEM/EDS images, and Petroleum Engineer Sofia Forestieri da Gama Rodrigues for revising this text.

\section{REFERENCES}

ALI SA, ERMEL E, CLARKE J, FULLER MJ, XIAO Z AND MALONE B. 2008. Stimulation of High-Temperature Sandstone Formations From West Africa With Chelating Agent-Based Fluids. SPE Prod Oper 23: 32-38.

ATWOOD SE AND WALLWEY DD. 1996. Ion chromatographic cation analysis of effluent waters from scale dissolver treatments. J Chromatogr A 739: 265-271.

BELLARBY J. 2009. Well Completion Design, $1^{\text {st }}$ ed., Oxford: Elsevier, $726 \mathrm{p}$

BIN MERDHAH AB AND YASSIN AM. 2008a. Formation damage due to scale formation in porous media resulting water injection. Emirates Journal for Engineering Research 13: 69-79.

BIN MERDHAH AB AND YASSIM AM. 2008b. Low-sulfate seawater injection into oil reservoir to avoid scaling problem. J Applied Sci 8: 1169-1178.

BIN MERDHAH AB, YASSIN AM AND MUHEREI MA. 2010. Laboratory and prediction of barium sulfate scaling at high-barium formation water. J Pet Sci Eng 70: 79-88.

COLLINS CH, BRAGA GL AND BONATO S. 2006. Fundamentos de Cromatografia, Campinas: UNICAMP, $453 \mathrm{p}$. 
DUNN K, DANIEL E, SHULER PJ, CHEN HJ, TANG Y AND YEN TF. 1999. Mechanisms of surface precipitation and dissolution of barite: a morphology approach. J Colloid Interface Sci 214: 427-437.

ECONOMIDES MJ AND NOLTE KG. 2000. Reservoir Stimulation, $3^{\text {rd }}$ ed., New York: J Wiley \& Sons, 856 p.

EL-SAID M, RAMZI M AND ABDEL-MOGHNY T. 2009. Analysis of oilfield waters by ion chromatography to determine the composition of scale deposition. Desalination 249: 748-756.

FINK JK. 2012. Petroleum Engineer's Guide to Oil Field Chemicals and Fluids, $1^{\text {st }}$ ed., Oxford: Elsevier, 808 p.

HARRIS DC. 2001. Exploring Chemical Analysis, $1^{\text {st }}$ ed., New York: W.H. Freeman and Company, 608 p.

JORDAN MM, GRAHAM GM, SORBIE KS, MATHARU A, TOMLINS R AND BUNNEY J. 2000. Scale dissolver application: production enhancement and formationdamage potential. SPE Prod Facil 15: 288-295.

KALFAYAN L. 2008. Production enhancement with acid stimulation, $2^{\text {nd }}$ ed., Tulsa: Penn Well Books, $252 \mathrm{p}$.

MACKAY E. 2003. Predicting in situ sulphate scale deposition and the impact on produced ion concentrations. Trans IChemE 81: 326-332.

MACKAY EJ, JORDAN MM AND TORABI F. 2003. Predicting brine mixing deep within the reservoir and its impact on scale control in marginal and deep water developments. SPE Prod Facil 18: 210-220.

MONTANHEIRO TJ, ARTUR AC, MONTANHEIRO F, NEGRI FA, GESICKI AL AND BOGGIANI PC. 2011. Investigação tecnológica de arenitos silicificados da Formação Botucatu (NE do Paraná) para uso como rocha de revestimento. Geociências 30: 237-251.

PUTNIS CV, KOWACZ M AND PUTNIS A. 2008. The mechanism and kinetics of DTPA-promoted dissolution of barite. Appl Geochem 23: 2778-2788.
REIS MIP, DA SILVA FC, ROMEIRO GA, ROCHA AA AND FERREIRA VF. 2011. Deposição Mineral em Superfícies: Problemas e Oportunidades na Indústria do Petróleo. Rev Virtual Quim 3: 2-13.

ROSA AJ, CARVALHO RS AND XAVIER JAD. 2006. Engenharia de Reservatórios de Petróleo, Rio de Janeiro: Interciência, 808 p.

SHAW SS, SORBIE K AND BOAK LS. 2012. The effects of barium sulfate saturations ratio, calcium, and magnesium on the inhibition efficiency - Part I: phosphonate scale inhibitors. SPE Prod Oper 27: 306-317.

TODD AC AND YUAN MD. 1992. Barium and strontium sulfate solid-solution scale formation at elevated temperatures. SPE Prod Eng 7: 85-92.

TOMSON MB, FU G, WATSON MA AND KAN AT. 2003. Mechanisms of mineral scale inhibition. SPE Prod Facil 18: 192-199.

WANG KS, RESCH R, DUNN K, SHULER P, TANG Y, KOEL BE AND YEN TF. 1999. Dissolution of the barite (001) surface by the chelating agent DTPA as studied with non-contact atomic force microscopy. Colloids Surf A 160: 217-227.

\section{SUPPLEMENTARY MATERIAL}

Figure S1 - SEM of barite before dissolution test, with resolution of 40x (a); SEM of barites after dissolution tests at $80{ }^{\circ} \mathrm{C}$ and $12 \mathrm{~h}$ : in 10 DTPA\% solution, with resolution of 50x (b); in 15 DTPA\% solution, with of 50x (c); in 25 DTPA\% solution, with resolution of $60 \mathrm{x}(\mathbf{d})$.

Figure S2 - (a) X-ray spectrum and chemical composition of region marked; (b) SEM of rock, in detail can be observed precipitate $\mathrm{BaSO}_{4}$ crystals (resolution of $1200 \mathrm{x}$ ). 